\title{
LAJU DEKOMPOSISI AWAL SERASAH POHON Palaquium obovatum, Spathodea campanulata dan Calophyllum soulattri DI HUTAN BRON WAREMBUNGAN KABUPATEN MINAHASA
}

\author{
THE INITIAL DECOMPOSITION RATE OF THE Palaquium obovatum, Spathodea \\ campanulata DAN Calophyllum soulattri in BRON WAREMBUNGAN FOREST MINAHASA \\ REGENCY
}

\author{
Juwita F. Rumambi'1), Martina A. Langi'2), dan Wawan Nurmawan'2) \\ 1)Mahasiswa S1 Program Studi Ilmu Kehutanan, Fakultas Pertanian Unsrat Manado, 95115 \\ 2)Staf Pengajar Program Studi Ilmu Kehutanan, Fakultas Pertanian Unsrat Manado, 95115
}

\begin{abstract}
The availability of nutrient inputs for soil fertility in forests is very important to preserve in an effort to anticipate a decrease in land productivity. Litter decomposition is a process of destruction of organic matter (litter) into nutrients available in the soil. This study aims to determine and compare the rate of decomposition of Palaqium obovatum, Spathodea campanulata, and Calophyllum soulattri litter in Bron Warembungan Forest, Minahasa Regency. This study was carried out on the leaf litter of Palaqium obovatum, Spathodea campanulata, and Calophyllum soulattri. The method of decomposition rate data collection using 36 litter bags placed randomly (with experiments using a completely randomized design (CRD) with two factors namely tree type and duration of decomposition) on the forest floor taken every week for four weeks, followed simultaneously with temperature measurements and humidity. The results showed that of the three main tree species in Bron Forest, the highest decomposition rate was shown by leaf litter of Spathodea campanulata with an average of $15.49 \%$ per week, followed by Palaquium obovatum (11.74\% per week) and then Calophyllum soulattri ( $3.07 \%$ per week). The decomposition process in the three leaf litter took place very quickly in the first week which can also be associated with the results of measurements of water content in litter.
\end{abstract}

Keywords: tropical rainforest, decomposition of litter, leaf litter

\begin{abstract}
ABSTRAK
Ketersediaan masukan hara bagi kesuburan tanah di hutan sangat penting dijaga kelestariannya dalam upaya mengantisipasi terjadinya penurunan produktivitas lahan. Dekomposisi serasah merupakan suatu proses penghancuran bahan organik (serasah) menjadi unsur-unsur hara yang tersedia di tanah. Penelitian ini bertujuan untuk mengetahui serta membandingkan laju dekomposisi serasah pohon Palaqium obovatum, Spathodea campanulata, dan Calophyllum soulattri di Hutan Bron Warembungan, Kabupaten Minahasa. Penelitian ini dilakukan pada serasah daun Palaqium obovatum, Spathodea campanulata, dan Calophyllum soulattri. Metode pengumpulan data laju dekomposisi menggunakan 36 kantong serasah yang diletakkan secara acak (dengan percobaan menggunakan rancangan acak lengkap (RAL) dengan dua faktor yaitu jenis pohon dan durasi dekomposisi) di lantai hutan diambil setiap minggu sekali selama empat minggu, diikuti serentak dengan pengukuran suhu dan kelembaban. Hasil penelitian menunjukkan bahwa dari ketiga jenis pohon utama di Hutan Bron, laju dekomposisi tertinggi ditunjukkan oleh serasah daun Spathodea campanulata dengan rata-rata $15,49 \%$ per minggu, diikuti oleh Palaquium obovatum (11,74\% per minggu) dan selanjutnya Calophyllum soulattri ( $3,07 \%$ per minggu). Proses dekomposisi pada ketiga serasah daun tersebut berlangsung sangat cepat pada minggu pertama yang dapat pula dikaitkan dengan hasil pengukuran kandungan air pada serasah.

Kata kunci: hutan hujan tropis, dekomposisi serasah, serasah daun
\end{abstract}




\section{PENDAHULUAN}

Peran serasah atau jatuhan jaringan mati dalam proses ketersediaan hara bagi tumbuhan sangat bergantung pada laju produksi serasah serta dekomposisinya. Jenis tumbuhan yang berbeda menghasilkan substrat serasah yang berbeda pula yang selanjutnya akan mempengaruhi kecepatan berdekomposisi. Menurut Proctor (2003), faktorfaktor yang mempengaruhi produksi serasah adalah faktor lingkungan (iklim, ketinggian tempat, kesuburan tanah), faktor jenis tumbuhan pembentuk hutan, serta faktor waktu (musim, umur tegakan).

Dekomposisi serasah adalah proses perombakan serasah oleh jasad renik (mikroba) menjadi energi dan elemen anorganik yang lebih sederhana seperti karbon, nitrogen, fosfor, belerang, dan kalium. Proses dekomposisi melibatkan perubahan secara fisik maupun secara kimiawi oleh organisme mikro tanah, dan sering disebut mineralisasi. Dekomposisi berlangsung secara dinamis dan sangat dipengaruhi oleh keberadaan dekomposer baik jumlah maupun diversitasnya (Aber and Mellilo, 2005).

Stasiun Penelitian Hutan Bron merupakan hutan pendidikan yang dikelola oleh Program Studi IImu Kehutanan Universitas Sam Ratulangi bekerja sama dengan Balai Pengelolaan DAS (BPDAS) Tondano dan Dinas Kehutanan Minahasa, saat ini digunakan sebagai kawasan Laboratorium Silvikultur Intensif (Tasirin, 2012). Hutan Bron dikenal sebagai lokasi mata air dan penyuplai kebutuhan air bersih oleh masyarakat Kota Manado dan sekitarnya yang keeberadaannya dijaga kelestariannya selain sebagai sumber mata air, juga untuk mempertahankan fungsi-fungsi ekologis lainnya seperti kesuburan tanah bagi kegiatan pertanian masyarakat.

Berdasarkan hasil penelitian Melalolin (2016) di Hutan Bron, jenis vegetasi Palaquium obovatum, Spathodea campanulata, dan
Calophyllum sp. merupakan jenis pohon dominan di antara pe-pohonan yang ada.

Penelitian ini bertujuan untuk mengetahui serta membandingkan laju dekomposisi serasah daun pohon Palaquium obovatum, Spathodea campanulata, dan Calophyllum soulattri di Hutan Bron, Desa Warembungan, Kabupaten Minahasa.

Melalui penelitian ini diharapkan dapat diperoleh informasi ilmiah mengenai dinamika unsur hara yang dikembalikan ke sistem tanah, sehingga menjadi salah satu dasar rekomendasi dalam rangka pengelolaan hutan alam berkelanjutan.

\section{METODE PENELITIAN}

Penelitian dilaksanakan di Stasiun Penelitian Hutan Bron di Desa Warembungan, Kabupaten Minahasa pada bulan Juli dan Agustus 2017.

Bahan yang digunakan dalam penelitian ini adalah serasah daun dari pohon Palaquium obovatum, Spathodea campanulata, dan Calophyllum soulattri yang sudah dikeringanginkan. Alat berupa litter bag (kantong serasah) yang terbuat dari kain kasa atau nylon memiliki mata jala $1 \mathrm{~mm}$ berukuran $20 \times 13 \mathrm{~cm}$, kantong kertas (brown paper), meteran, tali plastik, jaring untuk menangkap serasah, label, timbangan digital, kamera, GPS, Thermohygrometer, alat tulis menulis, patok kayu atau bambu dan oven.

Penelitian ini menggunakan rancangan acak lengkap (RAL) sebagai rancangan percobaan dengan dua faktor. Faktor pertama adalah jenis pohon, dan faktor kedua adalah periode dekomposisi. Jumlah kantong serasah sebanyak 9 kantong setiap plot pengamatan.

Variabel yang diamati dalam penelitian ini adalah berat basah awal (gram), berat kering awal serasah (gram), berat kering akhir (gram), laju dekomposisi (\% per minggu), dan pengukuran suhu dan kelembaban $\left({ }^{\circ} \mathrm{C}\right)$. 


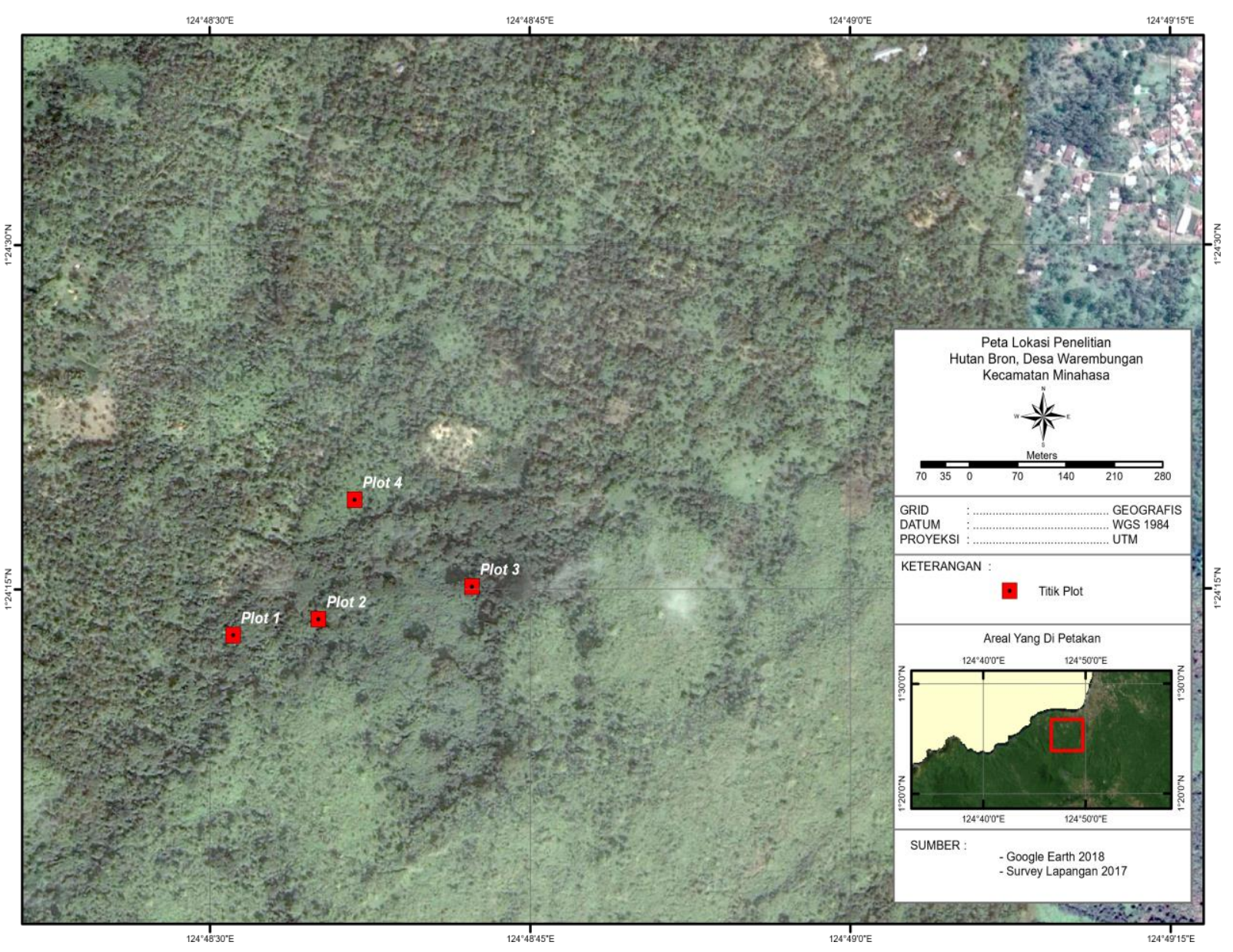

Gambar 1. Lokasi Penelitian di Desa Warembungan, Kabupaten Minahasa

(Figure 1. Research Sites in Warembungan Village, Minahasa Regency)

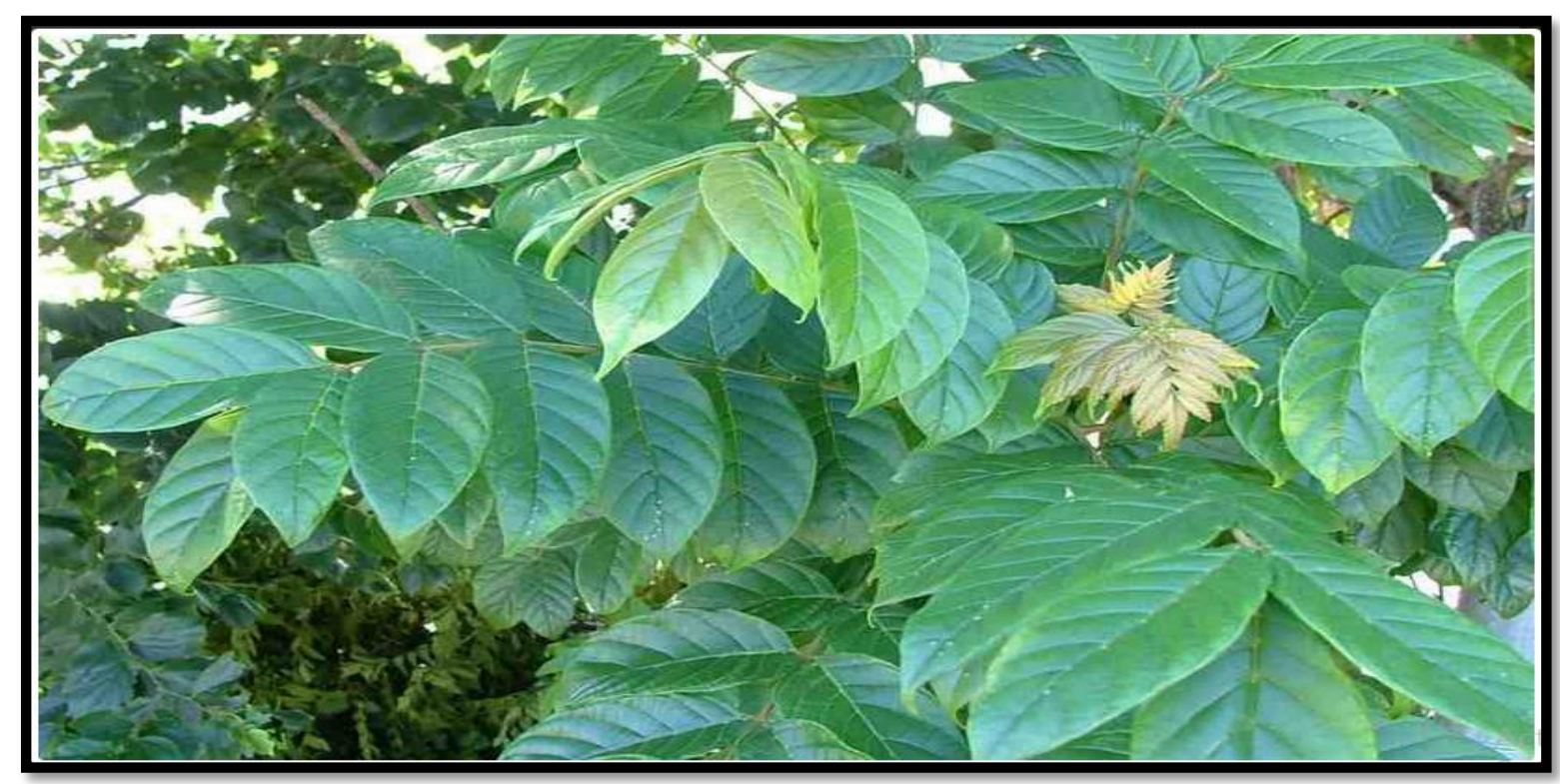

Gambar 2. Daun Spathodea campanulata

(Figure 2. Spathodea campanulata leaves) 


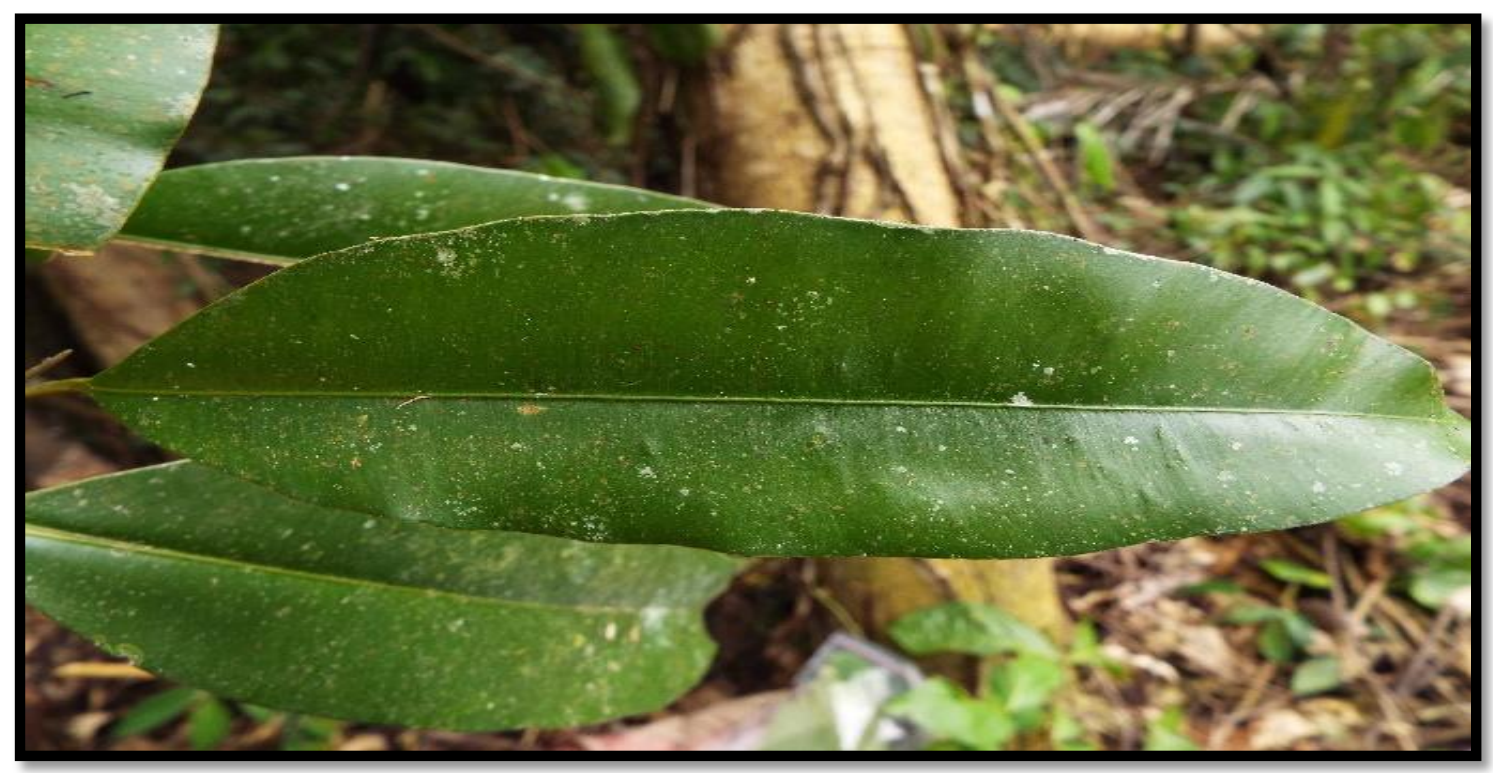

Gambar 3. Daun Calophyllum soulattri

(Figure 3. Calophyllum soulattri Leaves)

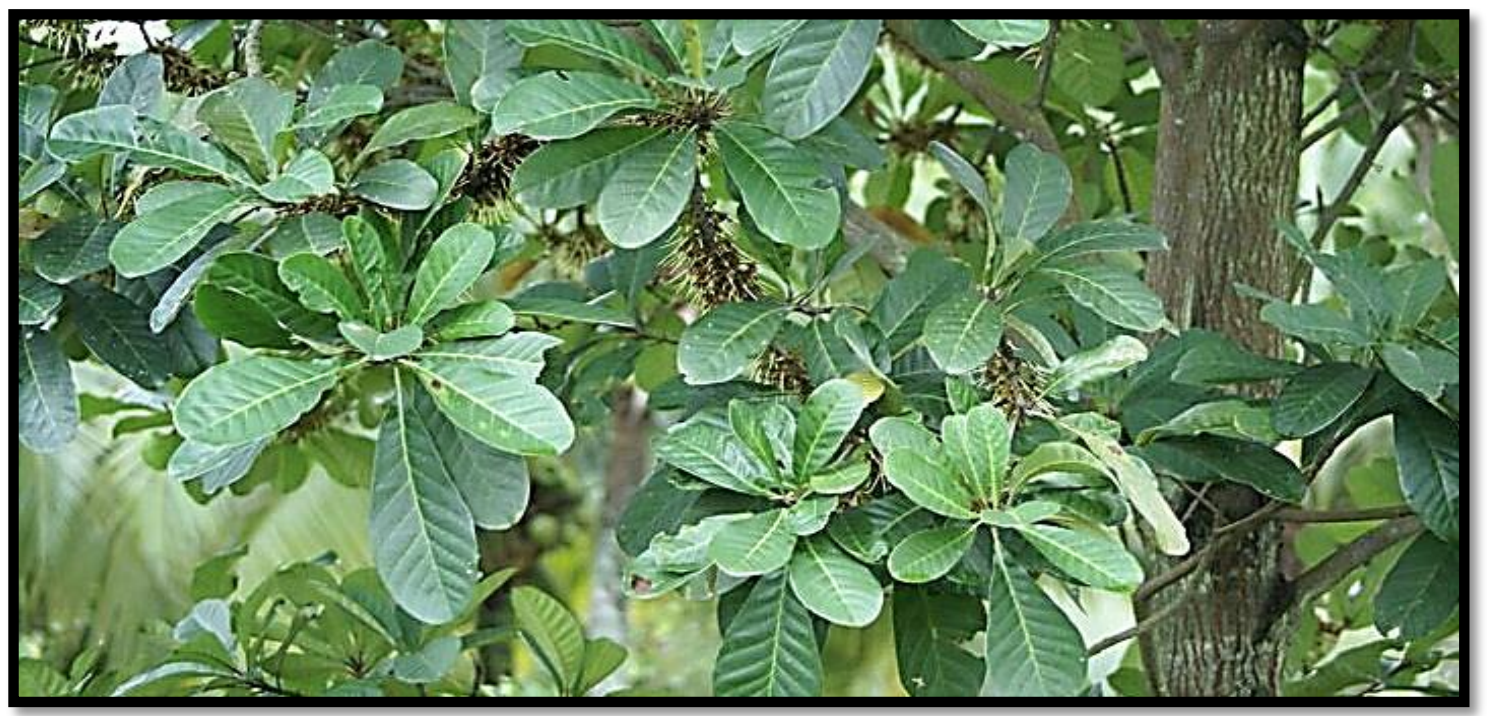

Gambar 4. Daun Palaquium obovatum

(Figure 4. Palaquium obovatum Leaves)

\section{Prosedur Kerja}

Pengambilan serasah segar (serasah daun yang jatuh dari pohon dengan kondisi bentuk yang masih utuh) yang ditampung di atas tikar atau jaring serasah selama tiga hari, setelah itu dikeringanginkan selama satu hari. Serasah daun dimasukkan ke dalam kantong serasah sebanyak 10 gram berat basah per kantong. Jumlah kantong serasah sebanyak 36 kantong ( 3 jenis $\times 4$ kali pengumpulan $\times 3$ ulangan) ditambah 9 kantong serasah sebagai kontrol data berat kering awal serasah $(W o)$ diberi tanda atau label dari setiap kantong serasah untuk membedakan jenis serasah dan disebarkan secara acak di lantai hutan. Agar tidak hilang atau berpindah tempat diikatkan pada patok bambu. Setiap seminggu sekali diambil sembilan kantong serasah serta dilakukan pengukuran suhu dan kelembaban di lokasi penelitian selama empat minggu. Sampel kantong serasah dibawa ke laboratorium dan dibersihkan dari tanah yang menempel pada sampel untuk dikeringkan ke dalam oven selama 8 jam dengan suhu $50^{\circ} \mathrm{C}$ lalu ditimbang untuk didapatkan 
data berat kering serasah daun. Tata letak (layout) titik pengambilan kantong serasah ditampilkan pada Gambar 5. Data penunjang seperti curah hujan yang diperoleh dari BMKG (Badan Meteorologi
Klimatologi dan Geofisika) sebagai penunjang dalam laju dekomposisi serasah yang berada di lokasi penelitian.

\section{$20 \mathrm{~m}$}

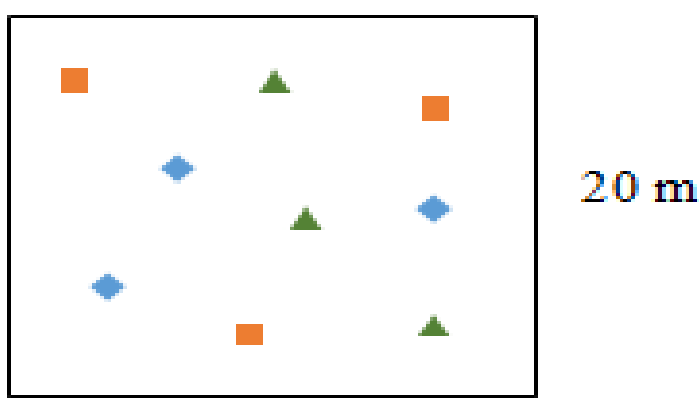

Gambar 5. Layout Peletakan Kantong Serasah di Lapangan

(Figure 5. Layout Laying Litter Bags in the Field)

\section{Keterangan:}

Kantong serasah Palaqium obovatum

- Kantong serasah Spathodea campanulata

A Kantong serasah Calophyllum soulattri

\section{Analisis Data}

Penelitian ini menggunakan analisis data laju dekomposisi sebagai berikut:

Penurunan bobot serasah didapat dengan rumus:

$W \alpha=\frac{W o-W t}{W o} \times 100 \%$

dimana:

Wo $=$ berat kering awal serasah (gram)

$\mathrm{Wt}=$ berat kering akhir serasah (gram) per periode waktu $t$

$W a=$ penurunan bobot $(\%)$

Laju dekomposisi diduga dengan rumus :

$D=\frac{\mathrm{W} \alpha}{\text { minggu }}$

$\mathrm{D}=$ pendugaan laju dekomposisi (\% per minggu)

Dilanjutkan dengan analisis ANOVA untuk menghitung penurunan bobot serasah perminggu. Data yang diperoleh berupa data perminggu yang ditampilkan dalam bentuk grafik dalam perbandingan 3 (tiga) jenis pohon (Palaquium obovatum, Spathodea campanulata, dan Calophyllum soulattri).

\section{HASIL DAN PEMBAHASAN}

Perbandingan Laju Dekomposisi Serasah Pohon Palaquium obovatum, Spathodea campanulata, dan Calophyllum soulattri

Laju dekomposisi serasah daun Palaquium obovatum, Spathodea campanulata, dan Calophyllum soulattri dapat dihitung dari perubahan bobot kering serasah selama proses dekomposisi. Perubahan bobot serasah per satuan waktu dalam proses dekomposisi dipengaruhi oleh iklim dan aktivitas organisme mikro tanah dalam memanfaatkan kandungan karbon dari serasah sebagai bahan makanan lalu membebaskannya sebagai gas karbondioksida. Hasil pengamatan menunjukkan laju dekomposisi serasah daun berbeda pada setiap jenis pohon (Tabel 1). 
Tabel 1. Perbandingan Laju Dekomposisi Serasah Daun Palaquium obovatum, Spathodea campanulata, dan Calophyllum soulattri

(Table 1. Comparison of the Rate Decomposition Leaf Litter of Palaquium obovatum, Spathodea campanulata, dan Calophyllum soulattri)

\begin{tabular}{cccccccccc}
\hline \multirow{2}{*}{$\begin{array}{c}\text { Waktu } \\
\text { (Minggu) }\end{array}$} & \multicolumn{3}{c}{ Palaquium obovatum ${ }^{* *}$} & \multicolumn{3}{c}{ Spathodea campanulata** } & \multicolumn{3}{c}{ Calophyllum soulattri* $^{* *}$} \\
\cline { 2 - 10 } & \multicolumn{1}{c}{ Wt } & Wa & $D^{*}$ & Wt & Wa & $D^{*}$ & Wt & Wa & D \\
\cline { 2 - 10 } 1 & 4,13 & 17,39 & 17,39 & 2,43 & 19,02 & 19,02 & 6,41 & 4,52 & 4,52 \\
2 & 3,83 & 23,47 & 11,73 & 2,09 & 30,44 & 15,22 & 6,34 & 5,53 & 2,77 \\
3 & 3,63 & 27,39 & 9,13 & 1,69 & 43,76 & 14,59 & 6,21 & 7,59 & 2,53 \\
4 & 3,26 & 34,79 & 8,70 & 1,43 & 52,48 & 13,12 & 6,05 & 9,86 & 2,47 \\
& Rata-rata & & 11,736 & Rata-rata & 15,487 & Rata-rata & 3,071 \\
\hline
\end{tabular}

(**)Jenis pohon berpengaruh signifikan; $\left({ }^{*}\right)$ periode waktu berpengaruh signifikan terhadap laju dekomposisi

Keterangan :

$\mathrm{Wt}=$ berat kering serasah (gram)

Wa $=$ penurunan bobot $(\%)$

$\mathrm{D}$ = pendugaan laju dekomposisi (\% per minggu)

Setelah terdekomposisi selama 4 minggu, serasah daun yang paling cepat terdekomposisi ialah serasah daun Spathodea campanulata yang mengalami penurunan bobot sebesar $52,48 \%$ dari bobot kering awal sebesar 3 gram dengan rata-rata laju dekomposisi $15,487 \%$ per minggu. Serasah daun Palaquium obovatum mengalami penurunan bobot sebesar $34,79 \%$ dari bobot kering awal sebesar 5 gram dengan rata-rata laju dekomposisi $11,736 \%$ per minggu dan serasah daun Calophyllum soulattri mengalami penurunan bobot sebesar $9,86 \%$ dari bobot kering awal sebesar 6,7 gram dengan rata-rata laju dekomposisi 3,071 \% per minggu.

Secara fisik perubahan stuktur serasah daun Spathodea campanulata mudah hancur dibandingkan dengan kedua jenis lainnya. Ciri-ciri fisik daun Spathodea campanulata yang memiliki permukaan licin; pertulangan menyirip dan pola tulang tersier menangga tali; daging daun (intervenium) tipis seperti selaput dan lunak, yang membuat serasah daun lebih mudah terdekomposisi. Serasah daun Palaquium obovatum yang juga mudah terdekomposisi memiliki ciri-ciri daun seperti permukaan atas daun gundul, permukaan bawah menyutra, tulang daun sekunder 916 pasang, daging daun tipis seperti kertas. Sedangkan serasah yang pelan terdekomposisi yaitu serasah daun Calophyllum soulattri dengan ciri-ciri daun seperti pertulangan menyirip rapat, daging daun seperti kulit (coriaceus), kaku, permukaan bawah licin kusam, permukaan atas licin mengilap. Demikian secara karakteristik daun dan komposisi serasah menentukan kualitas serasah yang menjadi sumber makanan bagi organisme pengurai (Nafia, 2009).

Perbandingan proses dekomposisi serasah
daun Palaquium obovatum, Spathodea campanulata, dan Calophyllum soulattri disajikan pada Gambar 6. Pada minggu pertama proses dekomposisi serasah daun ketiga jenis pohon tersebut mengalami proses laju dekomposisi yang tinggi dan perlahan-lahan melambat pada mingguminggu berikutnya, dimana pada awalnya serasah terurai dengan cepat kemudian semakin lambat dengan semakin lama periode waktu serasah terdekomposisi. 


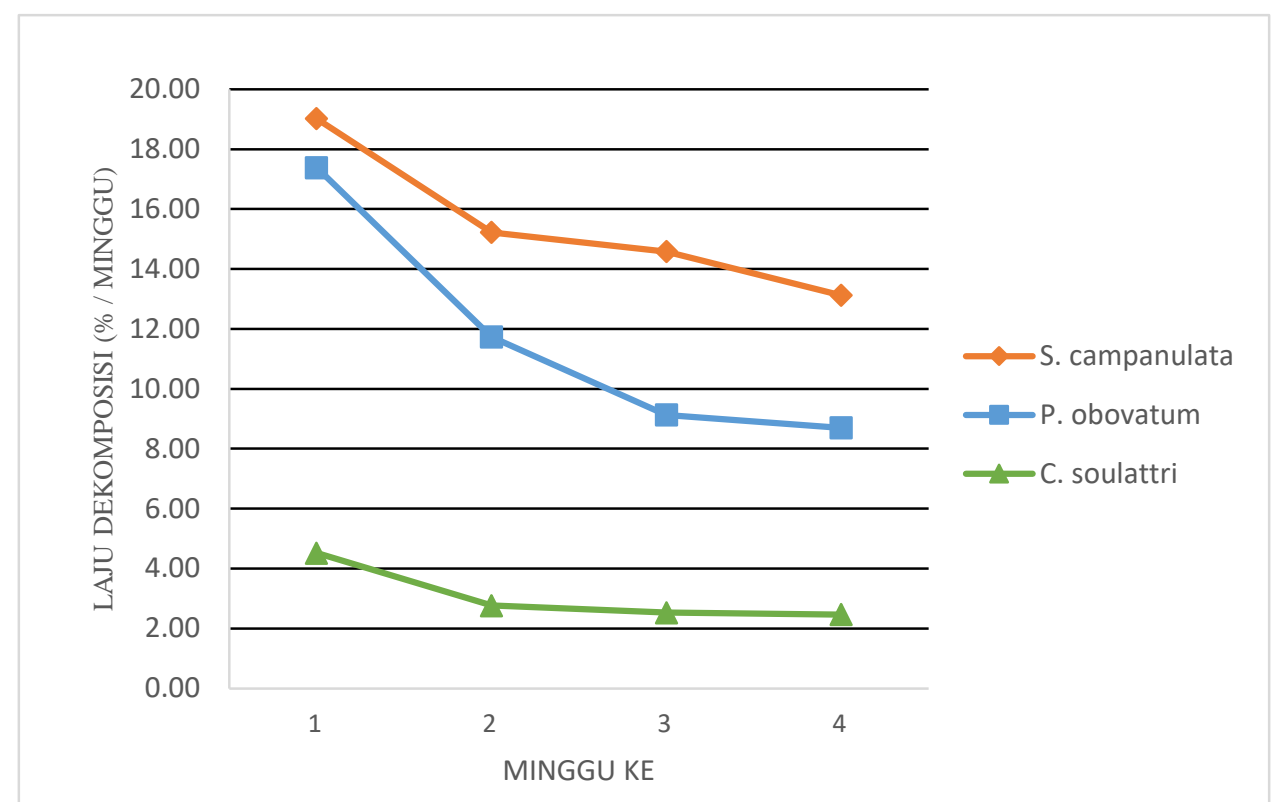

Gambar 6. Perbandingan Proses Dekomposisi Serasah Daun Palaquium obovatum, Spathodea campanulata dan Calophyllum soulattri.

(Figure 6. Comparison of the Decomposition Process of Leaf Litter of Palaquium obovatum, Spathodea campanulata dan Calophyllum soulattri.)

Kehilangan berat serasah umumnya pada minggu pertama dimana bahan yang mudah larut pada serasah didalamnya terdapat glukosa, phenolic, dan asam amino dan bahan yang sukar larut umumnya terdiri dari lignin, cellulose, dan xylan (Sulistiyanto, dkk., 2005). Menurut Abdul (2017), tingginya kandungan organik pada serasah pada awal periode waktu yang mengalami penghancuran sehingga terjadi penurunan laju dekomposisi serasah setiap periode waktunya. Kecepatan dekomposisi didukung oleh kualitas serasah itu sendiri dengan bahan yang dibutuhkan organisme mikro tanah untuk keberlansungan hidup. Semakin besar penurunan berat kering maka akan terjadi peningkatan laju dekomposisi (Hanum dan Kuswytasari, 2014).Berdasarkan hasil analisis keragaman pada jenis pohon diketahui bahwa faktor jenis pohon terhadap laju dekomposisi serasah didapatkan $\mathrm{F}$ hitung (20.995) > F tabel (3.285) yang berarti faktor jenis pohon berpengaruh secara signifikan terhadap laju dekomposisi serasah. Hal ini dikarenakan ketiga jenis pohon yang berbeda sehingga bahan yang terkandung dalam daun juga berbeda. Berdasarkan hasil analisis keragaman pada jenis pohon diketahui bahwa faktor periode waktu (minggu) terhadap laju dekomposisi serasah daun Palaquium obovatum dan Spathodea campanulata didapatkan $\mathrm{F}$ hitung $>\mathrm{F}$ tabel berpengaruh secara signifikan terhadap laju dekomposisi serasah. Hal yang dapat diartikan semakin lama waktu dekomposisi, maka semakin rendah laju dekomposisi serasah perperiodenya. Berbeda halnya dengan Calophyllum soulattri didapatkan $F$ hitung (2.358) < $\mathrm{F}$ tabel (4.066) yang berarti faktor jenis pohon tidak berpengaruh secara signifikan terhadap laju dekomposisi serasah. Hal ini diduga serasah daun Calophyllum soulattri memiliki komposisi serasah yang sulit dirombak oleh organisme mikro sehingga penurunan laju dekomposisi sangat lambat.

\section{Kandungan Air dan Kondisi Lingkungan Selama Proses Dekomposisi}

Kandungan air serasah daun lebih tinggi pada minggu pertama yaitu sebesar $5,97 \%$ untuk jenis Palaquium obovatum, $11,27 \%$ untuk jenis Spathodea campanulata, dan $5,24 \%$ untuk jenis Calophyllum soulattri dibanding minggu-minggu setelahnya (dilihat pada Gambar 7). Didukung dengan hasil pengukuran suhu $\mathrm{x}$ dengan 
kelembaban 69\% -79,7\% (Gambar 8 dan Gambar 9), dan data BMKG (2017) curah hujan bulanan menunjukkan pada wilayah Warembungan dan sekitarnya sewaktu pengamatan memilki volume curah hujan rendah pada lingkungan yang panas dan lembab dapat mendorong tingkat aktivitas organisme mikro yang tinggi. Aktivitas organisme mikro dan fauna tanah meningkat seiring dengan peningkatan suhu. Suhu dan kelembaban yang dipengaruhi curah hujan merupakan faktor iklim sangat menentukan keragaman organisme tanah.

Pada minggu keempat, tinggi kandungan air serasah dikarenakan saat pengamatan di lapangan dalam keadaan hujan, kandungan air serasah untuk jenis Palaquium obovatum sebesar $2,66 \%$, Spathodea campanulata sebesar 6,37 \%, dan Calophyllum soulattri sebesar 3,65\%. Serapan air hujan mengakibatkan kandungan air dalam serasah meningkat. Memiliki suhu yang menurun dengan suhu sekitar $23^{\circ} \mathrm{C}-24^{\circ} \mathrm{C}$ dan kelembaban naik sekitar $96 \%$ - $99 \%$, dan data BMKG (2017) curah hujan bulanan menunjukkan bahwa di wilayah Warembungan dan sekitarnya pada waktu pengamatan memilki volume curah hujan menengah pada bulan Agustus volume curah hujan sebesar $106 \mathrm{~mm}$. Perubahan frekuensi dan distribusi curah hujan dapat mempengaruhi dekomposisi serasah. Proses pencucian serasah secara fisik dikendalikan oleh curah hujan. Semakin tinggi volume curah hujan dapat mempercepat pemecahan serasah dan tanah-tanah yang tidak tertutupi vegetasi rentan terhadap pencucian yang akan mengurangi kesuburan tanah dengan cepat (Devianti, dkk., 2017).

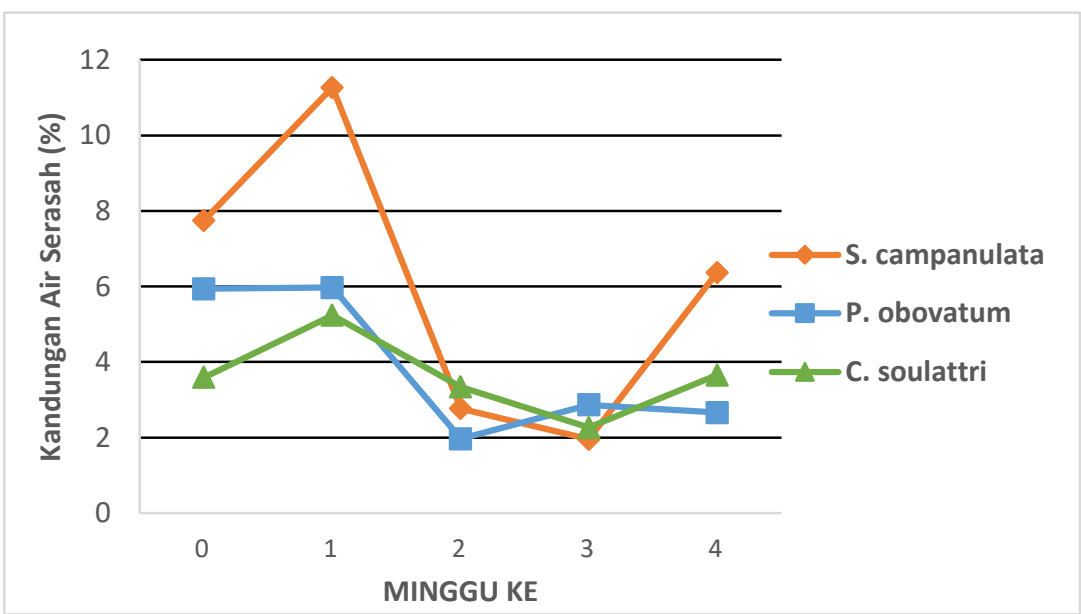

Gambar 7. Kandungan Air Pada Serasah Daun

(Figure 7. Water Content in Leaf Litter)

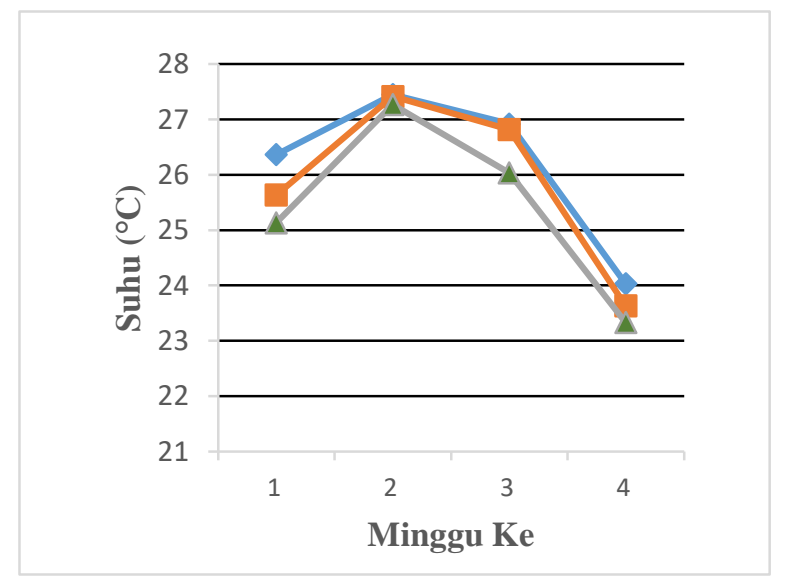

Gambar 8. Suhu Lingkungan (Figure 8. Environment Temperate)

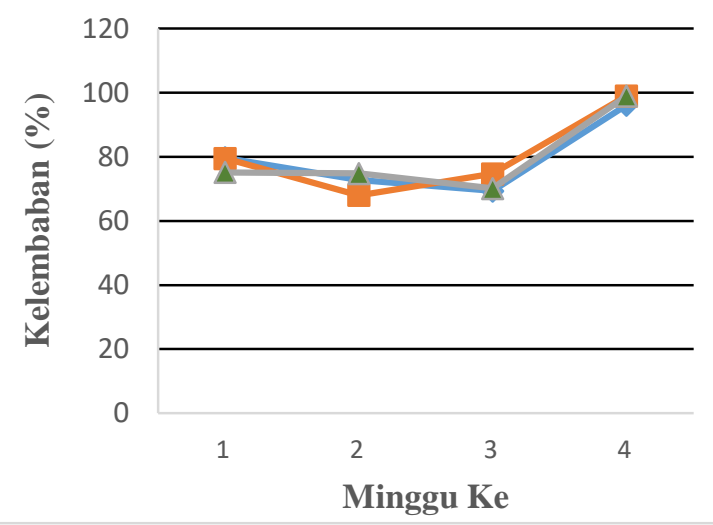

Gambar 9. Kelembaban Lingkungan (Figure 9. Environment Humidity) 


\section{KESIMPULAN DAN SARAN}

\section{Kesimpulan}

Dari ketiga jenis pohon utama di Hutan Bron, jenis dengan penurunan berat tertinggi ditunjukkan oleh Spathodea campanulata dengan rata-rata $15,49 \%$ per minggu. Jenis berikutnya adalah Palaquium obovatum dengan penurunan berat sebesar $11,74 \%$ per minggu, dan selanjutnya Calophyllum soulattri dengan penurunan berat sebesar $3,07 \%$ per minggu. Serasah ketiga jenis tersebut mengalami dekomposisi dengan laju tertinggi pada minggu pertama yaitu masing-masing sebesar $19,02 \%$ per minggu, $17,39 \%$ per minggu, dan 4,52 \% per minggu pada Spathodea campanulata, Palaquium obovatum, dan Calophyllum soulattri.

\section{Saran}

Penelitian lanjutan disarankan dapat dilakukan penambahan waktu pengamatan laju dekomposisi sampai mencapai total waktu dekomposisi, serta kandungan komposisi kimia serasah daun yang terdapat dalam serasah pohon Palaquium obovatum, Spathodea campanulata, dan Callophylum soulattri.

\section{DAFTAR PUSTAKA}

Abdul, M.M. 2017. Laju Penghancuran Serasah Daun Kuma (Palaquium luzoniense Fern) di Kawasan Hutan Lindung Nanga-nanga Papalia Kota Kendari Sulawesi Tenggara. Skripsi. Jurusan Biologi, Fakultas Matematika dan Pengetahuan Alam, Universitas halu Oleo. Kendari.

Aber, J. dan Melillo. 2005. Terrestrial Ecosystems. Saunders College Publishing, New York.
Devianti, O.K.A. dan T.D. Tjahjaningrum. 2017. Studi Laju Dekomposisi Serasah Pada Hutan Pinus di Kawasan Wisata Taman Safari Indonesia II Jawa Timur. Jurnal Sains dan Seni ITS 6(2):E81-E91.

Hanum, A. M. dan N.D. Kuswytasari. 2014. Laju Dekomposisi Serasah Daun Trambesi dengan Penambahan Inokulum Kapang. Jurnal Sains dan Seni Pomits 3(1):23373520.

Melalolin, S.B., M.T. Lasut, J.S. Tasirin, dan R.P. Kainde. 2016. Struktur dan Komposisi Vegetasi Pohon Di Stasiun Penelitian Hutan Bron Desa Warembungan Kabupaten Minahasa. Cocos 17(1):1-9.

Nafia, K. 2009. Potensi Jarak Pagar (Jathropa curcas Linn) Sebagai Jalur Hujau Ditinjau dari Laju Dekomposisi Serasahnya. Skiripsi. DePartemen Silvikultur, Fakultas Kehutanan, Institut Pertanian Bogor. Bogor.

Proctor, J. 2003. Tropical Litterfalls. In Tropical Rain Forest. Ecological and Management 2. Blackwell Scientific Publication. Oxford.

Sulistiyanto, Y., J.O. Rieley, dan S.H. Limin. 2005. Laju Dekomposisi Pelepasan Hara dari Serasah Pada Dua Sub-Tipe Hutan Rawa Gambut di Kalimantan Tengah. Jurnal Manajemen Tropika, 11(2):1-14.

Tasirin, J.S. 2012. Silvikultur Intensif. Program Studi Kehutanan, Fakultas Pertanian, Universitas Sam Ratulangi. Manado. 